\title{
Eid is Another Country
}

\section{Nadia Niaz}

A thick-plaited little girl, sequined top a-glitter, steps through the doors, her orange-patterned hand safe in her father's large, brown grasp.

She giggles, her glass bangles bright and clinking as she is jostled, sending ripples through her cheap silk lehenga, blocked gold embroidery holding

the hem still as the tram moves, a bright spot in the darkness.

I worry that she is cold.

The rainy grey of Melbourne is no place for Eid.

She should be ruining her fancy clothes with water fights, chasing cousins up trees and being rewarded with food, money, presents and her elders' blessing pats on the head for how much she's grown this year.

They must only see her in pictures now.

Or maybe one or two of them are here battling the cold as they cook kheer and seviyan. If they know to look for vermicelli. If they can use this thin milk, this watery sugar to recall home and family. 
The girl's accent carries no memory.

She was born here perhaps or brought

so young she doesn't remember

the smell of sweet milk thickening with heat

blanketing the city, the town, the country

the moment the moon is spotted

and the Chand Raat cry goes up.

Maybe she's never heard the sirens, never seen the stalls they summon

bristling with bangles in more colours than you can imagine,

mehndi-wallas with their wood stamps and strange citrus dye that

makes your palms sting but looks pretty under the hasty filaments,

qatlamma and jalebi stands that materialise from the mist,

oil already

boiling, next to sugar cane juicers and their smell of

ginger, the crush of

people with one night to get tomorrow's Eid just right.

She knows nothing of that frenzy, her speech slow and nasal

As she tells her father her clothes are itchy. 